\title{
Risk Management of OHS for Landfilling Construction in Talangagung Edu- Tourism Landfill
}

\author{
Dhymas Sulistyono Putro ${ }^{1^{*}}$, Arief Rachmansyah ${ }^{2}$, Bagyo Yanuwiadi ${ }^{3}$ \\ ${ }^{1}$ Master Program of Environmental Management and Development, Graduate Program, University of Brawijaya, \\ Malang, Indonesia \\ ${ }^{2}$ Department of Civil Engineering, Faculty of Engineering, University of Brawijaya, Malang, Indonesia \\ ${ }^{3}$ Department of Biology, Faculty of Mathematics and Natural Sciences, University of Brawijaya, Malang, Indonesia
}

\begin{abstract}
Talangagung Edu-Tourism Landfill is one of the landfills in Indonesia that leads to the Edu-Tourism Landfill. Thus, there is a need for Occupational Health and Safety (OHS) risk management for workers to improve service to tourists. Aim of the study is to determine, identify, analyze, and compile hazard sources or injury potential and risk assessment in activities from technical workers in the work area of Talangagung Edu-Tourism, as well as risk control that can be applied to reduce the consequences of each hazard sources or injury potential. The data collected through observations, interviews, and brainstorming to all technical workers and a chief. The processing of occupational health and safety risk management data was based on the Job Safety Analysis (JSA) concept. The hazard source or injury potential identification finds 7 activities. Each of which several steps along with their hazard source or injury potential and consequences identified. There are 43 hazard sources or injury potentials, from which, based on the risk assessment, 14 are extreme (E), 12 are high (H), 2 are medium (M), and 15 are low (L). The control divided into two. Eight of the controls conducted by the management of Talangagung Edu-Tourism and seventeen of the rest controls suggested by the researcher. By applying OHS Risk Management, they will increase the number of tourists because it improves the quality of the workers in service.
\end{abstract}

Keywords: Job Safety analysis, OHS, risk management.

\section{INTRODUCTION*}

Waste is a serious problem for humans, including Indonesians. Therefore, further processing is required [1]. Wastes in Indonesia is processed by establishing a landfill, one which operates in Malang Regency, namely Talangagung Edu-Tourism Landfill. Talangagung Edu-Tourism Landfill is one of the landfills in Indonesia that leads to the Edu-Tourism Landfill. One of the supporting components is the workers. Workers who are in the work area of Talangagung Edu-Tourism will have the potential to be affected by sources of danger or potential injuries originating from the work environment $[2,3,4]$.

The Occupational Health and Safety (OHS) Risk Management for workers will increase workers' productivity, which will have an impact on maximum service to tourists of Talangagung Edu-Tourism Landfill $[5,6]$. The maximum service application of OHS risk management in the operation of landfills includes hazard source or injury potential identification, risk assessment,

\footnotetext{
${ }^{*}$ Correspondence address:

Dhymas Sulistyono Putro

Email : dhymassulistyono95@gmail.com

Address : Postgraduate School, University of Brawijaya, Mayjen Haryono No. 169, Malang, 65145.
}

and risk control [7]. Talangagung Edu-Tourism has visitors, which written in the guest book and the schedule of visits that have been made. It is necessary to conduct OHS risk management, to protect tourists along with the activities in the landfill. Thus OHS risk management needs to be applied in advance to the technical workers then the management can provide OHS risk management education to the tourists. This study aimed to determine the hazard sources or injury potential and risk assessment in activities from technical workers in the work area of Talangagung Edu-Tourism, as well as risk control that can be applied to reduce the consequences of each hazard sources or injury potential.

\section{METHOD}

\section{Research Location}

This research was conducted at the landfill of Talangagung Village in Kepanjen District, Malang Regency, located at $8^{\circ} 07^{\prime} 14.81^{\prime \prime} S$ and $112^{\circ} 33^{\prime} 43.00^{\prime \prime} \mathrm{E}$. This research was conducted in November - December 2018. The land area Talangagung Edu-Tourism is \pm 2 . $66 \mathrm{Ha}$. The landfill is fully managed by the Environmental Office of Malang Regency and managed by 13 technical workers and a chief. Its location showed in the following Figure 1. 


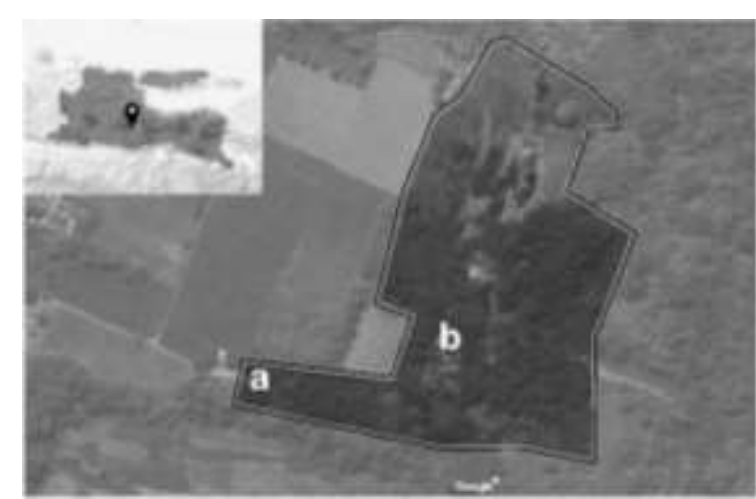

Figure 1. Talangagung landfill area, Kepanjen, Malang, East Java. (a) Office, (b) Hall

\section{Data Collection}

The data of this study collected through observations, interviews, and brainstorming. The observation carried out to observe and record directly the object of the study, namely hazard sources or injury potential. Observation of hazard sources or injury potential was based on activities from all technical workers of the Talangagung Edu-Tourism Landfill.

The interviews conducted to all technical workers of the Talangagung Edu-Tourism Landfill about their activities. The interviews will help in determining the hazard sources or injury potential, risk assessment of hazard sources or injury potential, and appropriate risk control based on each hazard sources or injury potential.

The brainstorming or group discussion was conducted in all OHS Risk Management stages using competencies from the researcher and all technical workers involved in the work area; they are 13 technical workers and a chief. It discussed hazard source or injury potentials identification, risk assessment, and risk control in their work area so far.

\section{Data Analysis}

The objective of the hazard source or injury potential identification is to determine hazard potential for the employees based on their tasks. The identification uses Job Safety Analysis (JSA) because this concept emphasizes the relationship between humans and their job [8]. In addition, the concept was selected based on the types and steps of the tasks. Once hazard potentials identified, risk assessment took place, using a risk matrix based on [8] standard, divided into the qualitative measure of Likelihood ( $L$ ) and Severity (S). The following Table 1, Table 2, and Table 3 were used in the risk assessment.

OHSAS 18001 provides risk control guidelines with several approaches; they are elimination, substitution, technical engineering, administration control, and Personal Protective Equipment (PPE) usage. Based on the guidelines, a risk management strategy to suppress likelihood, severity, and consequences, as well as risk transfers, are developed [9].

Table 1. Qualitative Measure of Likelihood

\begin{tabular}{cll}
\hline Level & Description & \multicolumn{1}{c}{ Detail } \\
\hline A & Almost Certain & Can happen at any time \\
B & Likely & Possibly frequent \\
C & Possible & Might happen occasionally \\
D & Unlikely & Rarely happen \\
E & Rare & Only in certain condition \\
\hline
\end{tabular}

Source: AS/NZS 4360:2004 [9]

Table 2. Qualitative Measure of Severity

\begin{tabular}{|c|c|c|}
\hline Level & Description & Detail \\
\hline 1 & Insignificant & No injury, small financial loss \\
\hline 2 & Minor & Mild injury, medium financial loss \\
\hline 3 & Moderate & $\begin{array}{l}\text { Medium injury, require medical } \\
\text { treatment, big financial loss }\end{array}$ \\
\hline 4 & Major & $\begin{array}{l}\text { Severe injury of more than one } \\
\text { person, big financial loss, } \\
\text { production disruption }\end{array}$ \\
\hline 5 & Catastrophic & $\begin{array}{l}\text { Fatal to more than one person, } \\
\text { massive losses and long-term } \\
\text { extensive effect, activity shut } \\
\text { down }\end{array}$ \\
\hline
\end{tabular}

Source: AS/NZS 4360:2004 [9]

Table 3. Risk Matrix

\begin{tabular}{cccccc}
\hline \multirow{2}{*}{ Likelihood } & \multicolumn{5}{c}{ Severity } \\
\cline { 2 - 6 } & $\mathbf{1}$ & $\mathbf{2}$ & $\mathbf{3}$ & $\mathbf{4}$ & $\mathbf{5}$ \\
\hline A & H & H & E & E & E \\
B & M & H & H & E & E \\
C & L & M & H & E & E \\
D & L & L & M & H & E \\
E & L & L & M & H & H \\
\hline
\end{tabular}

Notes: $\mathrm{E}=$ Extreme Risk, $\mathrm{H}=$ High Risk, $\mathrm{M}=$ Medium Risk, $\mathrm{L}=$ Low Risk

Source: AS/NZS 4360:2004 [9].

RESULT AND DISCUSSION

Hazard Source or Injury Potential Identification and Risk Assessment

Landfilling Construction consists of seven activities (Table 4). They are digging, coral stone arrangement, leachate drainage installation, methane harness installation, temporary landfill covering, and final landfill covering. In all seven activities, there are several steps along with their hazard source or injury potential and consequences. The digging consists of three steps, excavator mobilization, excavator footing determination, and excavation until the predetermined depth. During excavator mobilization and excavator footing determination, landfill covering takes place. 
Table 4. Result of Hazard Source or Injury Potential Identification and Risk Assessment

\begin{tabular}{|c|c|c|c|c|c|c|}
\hline \multirow{2}{*}{ Activity } & \multirow{2}{*}{ Steps } & \multirow{2}{*}{$\begin{array}{l}\text { Hazard Source or } \\
\text { Injury Potential }\end{array}$} & \multirow{2}{*}{ Consequences } & \multicolumn{3}{|c|}{ Risk Matrix } \\
\hline & & & & $\mathbf{S}$ & LL & RR \\
\hline \multirow[t]{10}{*}{ Soil Digging } & \multirow[t]{2}{*}{ Excavator Mobilization } & $\begin{array}{l}\text { Operators do not } \\
\text { have OHS license }\end{array}$ & $\begin{array}{l}\text { Heavy equipment does not } \\
\text { operate optimally }\end{array}$ & 1 & $\mathrm{C}$ & $\mathrm{L}$ \\
\hline & & $\begin{array}{l}\text { Distance with other } \\
\text { workers }\end{array}$ & $\begin{array}{l}\text { Heavy equipment endangers } \\
\text { other workers }\end{array}$ & 4 & $\mathrm{D}$ & $\mathrm{H}$ \\
\hline & \multirow[t]{4}{*}{$\begin{array}{l}\text { Excavator footing } \\
\text { determination }\end{array}$} & $\begin{array}{l}\text { Operators do not } \\
\text { have OHS license }\end{array}$ & $\begin{array}{l}\text { Heavy equipment does not } \\
\text { operate optimally }\end{array}$ & 1 & $\mathrm{C}$ & $\mathrm{L}$ \\
\hline & & $\begin{array}{l}\text { Distance with other } \\
\text { workers }\end{array}$ & $\begin{array}{l}\text { Heavy equipment endangers } \\
\text { other workers }\end{array}$ & 4 & $\mathrm{D}$ & $\mathrm{H}$ \\
\hline & & Waste slide & Buried & 2 & $\mathrm{D}$ & $\mathrm{L}$ \\
\hline & & Slippery Surface & Slipped & 2 & $\mathrm{D}$ & $\mathrm{L}$ \\
\hline & \multirow[t]{4}{*}{$\begin{array}{l}\text { Excavation until the } \\
\text { predetermined depth }\end{array}$} & $\begin{array}{l}\text { Operators do not } \\
\text { have OHS license }\end{array}$ & $\begin{array}{l}\text { Heavy equipment does not } \\
\text { operate optimally }\end{array}$ & 1 & $\mathrm{C}$ & $\mathrm{L}$ \\
\hline & & Landslide & Buried & 5 & A & $\mathrm{H}$ \\
\hline & & Slippery Surface & Slipped & 2 & $\mathrm{D}$ & $\mathrm{L}$ \\
\hline & & $\begin{array}{l}\text { Distance with other } \\
\text { workers }\end{array}$ & $\begin{array}{l}\text { Heavy equipment endangers } \\
\text { other workers }\end{array}$ & 4 & $\mathrm{D}$ & $\mathrm{H}$ \\
\hline \multirow{6}{*}{$\begin{array}{l}\text { Coral stone } \\
\text { arrangement }\end{array}$} & \multirow{3}{*}{$\begin{array}{l}\text { Inserting the mold drum into } \\
\text { the soil }\end{array}$} & Landslide & Buried & 3 & $\mathrm{~A}$ & $\mathrm{E}$ \\
\hline & & Slippery Surface & Slipped & 3 & $\mathrm{C}$ & $\mathrm{H}$ \\
\hline & & Ambient air quality & Respiratory problems & 3 & A & $\mathrm{E}$ \\
\hline & \multirow{3}{*}{$\begin{array}{l}\text { arranging the coral stone in } \\
\text { the drum }\end{array}$} & Landslide & Buried & 3 & A & $\mathrm{E}$ \\
\hline & & Slippery surface & Slipped & 3 & $\mathrm{C}$ & $\mathrm{H}$ \\
\hline & & Ambient air quality & Respiratory problems & 3 & A & $\mathrm{E}$ \\
\hline \multirow{5}{*}{$\begin{array}{l}\text { Leachate drainage } \\
\text { installation }\end{array}$} & \multirow{2}{*}{$\begin{array}{l}\text { Cutting holes of installation } \\
\text { pipes }\end{array}$} & Sharp drill tip & Injured worker's hands & 2 & $\mathrm{D}$ & $\mathrm{L}$ \\
\hline & & Pipe splinters & Entering the body & 2 & $\mathrm{C}$ & $M$ \\
\hline & \multirow{3}{*}{$\begin{array}{l}\text { Putting pipes vertically on } \\
\text { the landfill base }\end{array}$} & Landslide & Buried & 4 & $\mathrm{~A}$ & $E$ \\
\hline & & Slippery surface & Slipped & 3 & $\mathrm{C}$ & $\mathrm{H}$ \\
\hline & & Ambient air quality & Respiratory problems & 4 & $A$ & $E$ \\
\hline \multirow{7}{*}{$\begin{array}{l}\text { Methane harness } \\
\text { installation }\end{array}$} & \multirow{2}{*}{$\begin{array}{l}\text { Cutting holes of installation } \\
\text { pipes }\end{array}$} & Sharp drill tip & Injured worker's hands & 2 & $\mathrm{D}$ & $\mathrm{L}$ \\
\hline & & Pipe splinters & Entering the body & 2 & $\mathrm{C}$ & $\mathrm{M}$ \\
\hline & \multirow{3}{*}{$\begin{array}{l}\text { Putting pipes vertically on } \\
\text { the landfill base }\end{array}$} & Landslide & Buried & 4 & A & $\mathrm{E}$ \\
\hline & & Slippery surface & Slipped & 3 & $\mathrm{C}$ & $\mathrm{H}$ \\
\hline & & Ambient air quality & Respiratory problems & 4 & A & $\mathrm{E}$ \\
\hline & \multirow[t]{2}{*}{$\begin{array}{l}\text { Connecting pipe lines on } \\
\text { landfill to blowers }\end{array}$} & $\begin{array}{l}\text { Blower electric } \\
\text { current }\end{array}$ & Electric shock & 3 & $\mathrm{C}$ & $\mathrm{H}$ \\
\hline & & Ambient air quality & Respiratory problems & 2 & $\mathrm{~B}$ & $\mathrm{E}$ \\
\hline \multirow{3}{*}{$\begin{array}{l}\text { Temporary landfill } \\
\text { covering }\end{array}$} & Tarpaulin mobilization & Slippery surface & Slipped & 1 & $E$ & $\mathrm{~L}$ \\
\hline & \multirow[t]{2}{*}{ Tarpaulin spreading } & Landslide & Buried & 4 & $A$ & $E$ \\
\hline & & Slippery surface & Slipped & 3 & $\mathrm{C}$ & $\mathrm{H}$ \\
\hline \multirow[t]{12}{*}{ Final landfill covering } & \multirow[t]{2}{*}{ Excavator mobilization } & $\begin{array}{l}\text { Operators do not } \\
\text { have OHS license }\end{array}$ & $\begin{array}{l}\text { Heavy equipment does not } \\
\text { operate optimally }\end{array}$ & 1 & $\mathrm{C}$ & $\mathrm{L}$ \\
\hline & & $\begin{array}{l}\text { Distance with other } \\
\text { workers }\end{array}$ & $\begin{array}{l}\text { Heavy equipment endangers } \\
\text { other workers }\end{array}$ & 4 & $\mathrm{C}$ & $E$ \\
\hline & $\begin{array}{l}\text { Excavator footing } \\
\text { determination }\end{array}$ & $\begin{array}{l}\text { Operators do not } \\
\text { have OHS license }\end{array}$ & $\begin{array}{l}\text { Heavy equipment does not } \\
\text { operate optimally }\end{array}$ & 1 & C & $L$ \\
\hline & & Waste slide & Buried & 1 & $A$ & $\mathrm{H}$ \\
\hline & & Slippery surface & Slipped & 2 & $\mathrm{D}$ & $\mathrm{L}$ \\
\hline & & $\begin{array}{l}\text { Distance with other } \\
\text { workers }\end{array}$ & $\begin{array}{l}\text { Heavy equipment endangers } \\
\text { other workers }\end{array}$ & 4 & $\mathrm{C}$ & $E$ \\
\hline & & Landslide & Buried & 4 & $\mathrm{C}$ & $E$ \\
\hline & $\begin{array}{l}\text { Soil digging around the } \\
\text { landfill }\end{array}$ & $\begin{array}{l}\text { Operators do not } \\
\text { have OHS license }\end{array}$ & $\begin{array}{l}\text { Heavy equipment does not } \\
\text { operate optimally }\end{array}$ & 1 & $\mathrm{C}$ & $\mathrm{L}$ \\
\hline & & Waste slide & Buried & 1 & A & $\mathrm{H}$ \\
\hline & & Slippery surface & Slipped & 2 & $\mathrm{D}$ & $\mathrm{L}$ \\
\hline & & $\begin{array}{l}\text { Distance with other } \\
\text { workers }\end{array}$ & $\begin{array}{l}\text { Heavy equipment endangers } \\
\text { other workers }\end{array}$ & 4 & $\mathrm{C}$ & $E$ \\
\hline & & Landslide & Buried & 4 & $\mathrm{C}$ & $E$ \\
\hline
\end{tabular}

Notes: S= Severity (1-5), LL=Level of Likelihood (A-E), RR =Risk Rate; $E=$ Extreme Risk, H= High Risk, M= Medium Risk, L= Low Risk. 
There are several hazard sources or injury potentials of the landfill covering. First, operators of excavators do not have an OHS license, which cause suboptimal equipment operation, hence increasing the operational hour. Since the hazard source or injury potential does not cause either financial or physical loss, the risk categorized as low (L).

Second, the distance between the excavator and other personnel is close. Therefore, the risk is categorized as high $(\mathrm{H})$ and extreme (E). The difference in risk level caused by the fact that some workers are still in the landfill location during the final landfill covering to check the final condition of methane harness and leachate installation. It was different from the condition during the digging.

The hazard sources or injury potentials during the excavator footing determination are the operators of excavators do not have OHS license, waste slide, and slippery surface. Waste pile exceeding the excavator's height has the potential of a waste slide that may bury the operating excavator. This hazard source or injury potential is categorized into low $(\mathrm{L})$ and high $(\mathrm{H})$. The difference caused by the fact that the soil surface around the pile during the digging is more stable than during the final landfill covering, so the later activity has a higher risk.

The location of the Talangagung Edu-Tourism landfill tends to be slippery due to rainwater and scattering waste, becoming a hazard source for excavators during the digging and landfill covering, making it loses his footing. The risk assessment of both activities is low (L) risk. A similar risk assessment result is based on a similar hazard source or OHS risk and a similar unsafe condition [10].

The next hazard source or injury potential is a landslide that might happen to excavators. The risk level is high $(H)$ and extreme $(E)$. The high $(H)$ risk happens during the digging, where the soil is relatively stable, and the extreme (E) risk happens during the temporary landfill covering and final landfill covering, where the dug soil is relatively unstable and potential for collapsing.

The coral-stone arrangement consists of two steps; they are inserting the mold drum into the soil and arranging the coral stone in the drum. The extreme $(E)$ risk occurs in land sliding, which is different from the previous identification, i.e. on workers. The severity (S) of coral stone arrangement is 3 , while the severity of leachate drainage installation and methane harness installation is 4 . The different severity occurs because workers do not have to go into the landfill during the former activity, while workers have to go into the landfill during the later activities, exposing them with the risk of a landslide from the surface.

Hazard source or injury potential from a slippery surface is different from the previously mentioned, which endangers workers. The risk is high $(\mathrm{H})$, similar to those from leachate drainage installation and methane harness installation and final landfill covering when workers are spreading the tarpaulin. However, the risk of tarpaulin mobilization during the temporary landfill covering is low (L). The difference is caused by the fact, that the soil inclination and structure during the tarpaulin mobilization is relatively stable, and the mobilization takes place in different spots. The landfilling produces foully smelled Hydrogen Sulfide $\left(\mathrm{H}_{2} \mathrm{~S}\right)$, causing a decrease in ambient air quality and disturb human respiration $[11,12]$. The risk is extreme $(E)$, but the severity is different.

The severity of the coral stone arrangement is 3 because workers are surrounded by other landfills that are decomposing and producing methane byproducts that disturb respiration. During the methane harness installation, when workers set pipes vertically on the landfill base, the condition of the workers is similar to the condition during the coral stone arrangement, which requires workers to go into the landfill for methane harness installation. So the potential of having respiratory problems is higher with a score of 4 . In the same activity, during the step of connecting pipelines in the landfill to the blower, the severity is 2 , because the step is far from the landfilling location.

The hazard sources or injury potentials of leachate drainage installation are sharp drill tip, pipe splinters, landslide, slippery surface, and ambient air quality. The sharp drill tip can harm the worker's hand. The risk of this hazard source or injury potential is low (L) because the prevention is easy and the consequence is easy, to handle. The drilling causes pipe splinters that can enter the worker's respiration. The risk is medium (M) because the splinter is invisible, and the consequence is indirect. Both hazard sources and injury potentials found during methane harness installation. The environmental condition of the hazard sources or injury potentials is the same, so the risk levels are the same.

The hazard sources or injury potentials of methane harness installation are sharp drill tip, pipe splinter, landslide, slippery surface, ambient 
air quality, and electric current of the blower. All the hazard sources and injury potentials have been identified previously except the electric current. The distribution of methane to the community uses blowers that use electricity, exposing workers to the danger of electric shock. Since the consequence directly felt, the risk is high $(H)$.

The hazard sources or injury potentials of temporary landfill covering are slippery surface and landslide, while those of final land covering are operators of excavator do not have $\mathrm{OHS}$ license, the distance between workers, waste slide, slippery surface, and landslide, described in the previous activities. Table 4 is the result of hazard source or injury potential identification and risk assessment.

\section{Risk Control}

The result of risk assessment derived by applying risk control over each hazard source or injury potential. Thus the consequences can be minimized or even eliminated. Risk control divided into existing control, which has been conducted by Talangagung Edu-Tourism Landfill, and suggestion, which is the risk control recommended by the researcher (Table 5).

Lifting and transporting instruments must be operated by lifting and transporting instrument operators with OHS license and workbooks according to their types and qualifications [13]. Therefore, excavator operators must join training to obtain OHS license and must increase their knowledge in operating the equipment. Distance between workers and heavy equipment should be well determined in excavator operation by making prohibiting signs toward the operation of heavy equipment. Prohibition signs have the potential of reducing or eliminating consequences [14]. Waste slide makes excavators buried during the operation. It is advisable that the footing of the excavators set away from waste pile potential for sliding. Keeping the body away from hazard source or injury potential is a risk control [15].

The hazard source or injury potential of slippery surface is excavator and worker. In terms of the excavator, it is advisable to do maintenance, especially on the wheel system. In terms of the worker, the suggestion is on elimination control and PPE usage. For the former, it is advisable to pay attention to the slippery surface before entering the dugouts, while for the latter, it is advisable to provide appropriate protective shoes, such as those that do not absorb water and those with soles that help firm footing. Failure to use PPE and inappropriate use of PPE increases hazard or injury potential and its consequences [16].

As in the above, hazard source or injury potential of landslide is excavator and worker. In terms of the excavator, risk control accomplished by prioritizing non-landslide-potential soil. In terms of the worker, landslide potential should be checked the before entering the dugouts and intensify the communication with other workers on duty to inform the incoming hazard or injury potential. One of the obstacles to risk control is poor communication among workers [17].

Table 5. Result of Risk Control

\begin{tabular}{|c|c|}
\hline Existing Control & Suggestion \\
\hline $\begin{array}{l}\text { Excavator operators have received training from heavy } \\
\text { equipment producers }\end{array}$ & Sending excavator operators to trainings to obtain OHS license \\
\hline $\begin{array}{l}\text { Determining heavy equipment footing that is safe from } \\
\text { slippery surface and collapsing potential }\end{array}$ & $\begin{array}{l}\text { Determining a minimum distance during heavy equipment } \\
\text { operation }\end{array}$ \\
\hline Using protective shoes & $\begin{array}{l}\text { Keeping the footing of heavy equipment away from waste pile } \\
\text { with collapsing potential }\end{array}$ \\
\hline $\begin{array}{l}\text { Cutting off the working time by involving all workers } \\
\text { available }\end{array}$ & Maintaining the heavy equipment \\
\hline Medical checkup for all workers of the site & Prioritizing non-landslide-potential soil \\
\hline Keeping a safe distance between hand and sharp drill tip & Check the landslide potential before entering the dugouts \\
\hline Keeping a safe distance between nose and pipe & Intensifying the communication with other workers on duty \\
\hline \multirow[t]{9}{*}{ Choosing a more relatively stable footing } & Check the landslide potential before entering the dugouts \\
\hline & Providing appropriate protective shoes \\
\hline & Using appropriate breathing masks \\
\hline & Wearing appropriate protective gloves \\
\hline & Improving communication among involved workers \\
\hline & Wearing well insulated protective equipment \\
\hline & Using tools that help improve footing \\
\hline & Sending excavator operators to trainings to obtain OHS license \\
\hline & $\begin{array}{l}\text { Determining minimum safe distance during heavy equipment } \\
\text { operation }\end{array}$ \\
\hline
\end{tabular}


One of the hazard sources or injury potentials that is difficult to control is ambient air quality since it is difficult to identify. The controls that have been done are cutting off the working time by involving all workers available, and medical checkup by doctors from Kepanjen Health Center once in three months. Workers should use appropriate breathing masks, which can reduce the effect of low ambient air quality. There is a relationship between PPE usage and respiration health [18].

Sharp drill tip poses direct and immediate consequences, harming worker's hands. In addition to keeping a safe distance between the hand and sharp drill tip, workers should wear appropriate gloves when operating drills to reduce the hazard or injury potential. The particle of pipe splinter is very small, so it is difficult to see using bare eyes, and keeping a safe distance between nose and pipe during the drilling is not enough to reduce hazard or injury potential. Therefore, for risk, it is advisable to use appropriate breathing masks.

The blower was used during methane harness installation. The blower uses electricity, thus it has potential for electric shock. The advisable risk control is intensifying communication with other workers on duty and using well-insulated PPE such as those made of rubber, plastic, and cloth. Table 5 is the result of risk control in the landfilling construction.

\section{OHS Risk Management in Development of Edu- Tourism}

OHS risk management in Talangagung EduTourism Landfill will also have an impact on tourism development $[19,20]$. The application of OHS Risk Management to the workers is one of the supporting factors for increasing service to tourists, accompanied by an increase in workers' productivity while in the work area [21]. The enhancement in service will be increasing the number of tourists in Talangagung Edu-Tourism Landfill [22-25].

In addition, tourists will get information regarding the hazard sources or injury potential and consequences of the Talangagung EduTourism Landfill. The results of OHS risk management resulted in 2 hazard sources or injury potential, namely the ambient air quality and slippery surface. These are found in the work area of the Talangagung Edu-Tourism Landfill so that it will have an impact on the condition of tourists. Both hazard sources or injury potential and their consequences can be minimized or eliminated so risk control can provide appropriate protective shoes and breathing masks given to tourists or appealed before visiting.

\section{CONCLUSION}

The landfilling construction at Talangagung Edu-Tourism Landfill divided into several activities; they are digging, coral stone arrangement, leachate drainage installation, methane harness installation, temporary landfill covering, and final landfill covering. Each of which several steps has it's with their hazard source or injury potential and consequences.

We identified that there are 43 hazards sources or injury potentials, from which, based on the risk assessment, fourteen are extreme $(E)$, twelve are high $(\mathrm{H})$, two are medium $(\mathrm{M})$, and fifteen are low (L). Risk control is required to reduce the existing risk. The controls are as follows. Eight of the control has been done by the management of Talangagung Edu-Tourism, and seventeen of them suggested by the researcher. By applying OHS Risk Management, it will increase the number of visitors because it improves the quality of the workers in service.

\section{Acknowledgement}

The researcher would like to express his gratitude to the Environmental Office of Malang Regency as the manager of Talangagung EduTourism and all employees of the site for their hard work in helping the accomplishment of this research.

\section{REFERENCES}

[1] Mulasari, S. A., A. H. Husodo, and N. Muhadjir. 2014. Kebijakan pemerintah dalam pengelolaan sampah domestik. KESMAS National Public Health Journal 8(8), 404-410.

[2] Kasam. 2011. Analisis resiko lingkungan pada Tempat Pembuangan Akhir (TPA) sampah (Studi Kasus: TPA Piyungan Bantul). Jurnal Sains dan Teknologi Lingkungan 3(1), 19-30.

[3] President of Republic of Indonesia. 1970. Law of Republic of Indonesia No.1 about work safety. Republic of Indonesia. Jakarta.

[4] Harjanti, W. S, Y. H. Darundiati, and N. A. Y. Dewanti. 2016. Analisis risiko kesehatan lingkungan pajanan gas amonia $\left(\mathrm{NH}_{3}\right)$ pada pemulung di TPA Jatibarang, Semarang. Jurnal Kesehatan Masyarakat 4(3), 921-930.

[5] Denik, K., M. Al. Musadieq, and M. Djudi. 2017. Pengaruh Keselamatan Kerja dan Kesehatan Kerja (K3) terhadap motivasi 
kerja (studi pada karyawan Taman Rekreasi Sengkaling (TRS)). Jurnal Administrasi Bisnis 50(5), 102-107.

[6] Lestari, T. and E. Trisyulianti. 2009. Hubungan Keselamatan dan Kesehatan (K3) dengan produktivitas kerja karyawan (studi kasus: Bagian Pengolahan PTPN VIII Gunung Mas, Bogor). Jurnal Manajemen 1(1), 73-79.

[7] Handayani, D. I. 2018. Integrated risk management model related to Occupational Healthy and Safety in multi-storey buildings. Journal of Engineering and Management in Industrial System 6(1), 27-35.

[8] Ramli, S. 2010. Pedoman praktis dalam perspektif K3. PT. Dian Rakyat. Jakarta.

[9] Australian/New Zealand Standard 4360. 2004. AS/NZS 4360:2004: Risk Management. Sydney.

[10] Akbar, T. Y., S. Indarjo, A. S. Wahyuningsih, 2015. Penggunaan metode Hazard Identification Risk Assessment Control (HIRAC) dalam penyusunan program K3 untuk menurunkan angka kecelakaan kerja pada pekerja bagian pengamplasan PT Kota Jati Furnindo Desa Suwawal Kabupaten Jepara. Unnes Journal of Public Health 4(3), 24-31.

[11] Muspa, A., K. Kadir, Darmilan, N, Mappanganro, Hasyimuddin, and F. Nur. 2017. Penanggulangan bau sampah menggunakan ampas kopi (sebuah review). Proceeding of National Seminar Biology for Life. Gowa, 10 November 2017. 60-62.

[12] Andhika, R. and T. Agung. 2016. Pengaruh paparan $\mathrm{CH}_{4}$ dan $\mathrm{H}_{2} \mathrm{~S}$ terhadap keluhan gangguan pernapasan pemulung di TPA Mrican Kabupaten Ponorogo. Journal of Industrial Hygiene and Occupational Health 1(1), 1-14.

[13] Ministry of Labor and Transmigration, Republic of Indonesia. 2010. Regulation of Ministry of Labor and Transmigration No. 9 about operators and officers of aircraft and transport. Ministry of Labor and Transmigration. Jakarta.

[14] Ihsan, T., T. Edwin, and R. O. Irawan. 2016. Analisis risiko K3 dengan metode HIRARC pada area produksi PT Cahaya Murni Andalas Permai. Andalas Journal of Public Health 10(2), 179-185.

[15] Bramasto, T., and I. Zainafree. 2016. Penggunaan Job Safety Analysis dalam identifikasi risiko kecelakaan kerja di bagian workshop PT. Total Dwi Daya Kota
Semarang. Unnes Journal of Public Health 4(4), 94-106.

[16] Aryantiningsih, D. S., and D. Husmaryuli. 2016. Kejadian kecelakaan kerja pekerja Aspal Mixing Plant (AMP) \& Batching Plant di PT LWP Pekanbaru Tahun 2015. Andalas Journal of Public Health 10(2), 145-150.

[17] Alvan, A., and E. Widowati. 2016. Evaluasi penerapan ABg (Aktif Berbagi) sistem sebagai upaya mengurangi angka kecelakaan kerja di PT Coca-Cola Amatil Indonesia Central Java. Unnes Journal of Public Health 5(1), 19-28.

[18] Hutama, A. P. 2013. Hubungan antara masa kerja dan penggunaan alat pelindung diri dengan kapasitas vital pada pekerja Unit Spinning I Bagian Ring Frame PT. Pisma Putra Tekstil Pekalongan. Unnes Journal of Public Health 2(3), 1-9.

[19] Sudana, I M. A. and M. Sukana. 2018. Penerapan Keselamatan dan Kesehatan Kerja (K3) di daya tarik wisata Bali Treetop Adventure Park, Bedugul. Jurnal Destinasi Pariwisata 6(2), 224-228.

[20] Muka, I W. 2016. Property development risk analysis Mandalika Resort Lombok Tourism Area. The $2^{\text {nd }}$ International Conference on Civil Engineering Research (ICCER) 2016. IPTEK Journal of Proceedings Series 1, 4247.

[21] Firtriani, N., P. Deoranto, Dania, W. A. P. Dania. 2013. Analisis pengaruh Keselamatan dan Kesehatan Kerja (K3) terhadap produktivitas tenaga kerja dengan metode Partial Least Square. Industria: Jurnal Teknologi dan Manajemen Agroindustri (2)2, 93-104.

[22] Suharto. 2016. Studi tentang keamanan dan keselamatan pengunjung hubungannya dengan citra destinasi (studi kasus Gembira Loka Zoo). Jurnal Media Wisata 14(1), 287304.

[23] Williams, A. M., and V. Balaz, 2013. Tourism risk tolerance and competences: travel organization and tourism hazard. Tourism Management 35, 209-221.

[24] Seabra, C., S. Dolnicar, J. L. Abrantes, and E. Kastenholz. 2013. Heterogeneity in risk and safety perceptions of international tourists. Tourism Management 36, 502-510.

[25] Holm, M. R., P. Lugosi, R. R. Croes, and E. N. Torres. 2017. Risk-tourism, risk-taking and subjective well-being: a review and synthesis. Tourism Management 63, 115122. 